Engaging the Multi-generational Workforce in Tourism and Hospitality

Paul Barron, PhD (*)

School of Marketing, Tourism and Languages

Edinburgh Napier University

Craiglockhart Campus

Edinburgh

EH14 1DJ

p.barron@napier.ac.uk

Anna Leask, PhD

School of Marketing, Tourism and Languages

Edinburgh Napier University

Craiglockhart Campus

Edinburgh

EH14 1DJ

a.leask@napier.ac.uk

Alan Fyall, PhD

Rosen College of Hospitality Management

University of Central Florida

9907 Universal Boulevard

Orlando, FL. 32819

alan.fyall@ucf.edu

* Corresponding author 


\title{
Engaging the Multi-generational Workforce in Tourism and Hospitality
}

\begin{abstract}
Purpose

The purpose of this study is to present strategies that hospitality and tourism organisations might adopt as a means of encouraging employee engagement, thus enabling the more effective management of an increasingly multi-generational workforce. This paper evaluates current strategies being adopted that might encourage employee engagement by a selection of hospitality and tourism organisations and develop recommendations for organisations wishing to more effectively engage the multi-generational workforce.
\end{abstract}

\section{Design/methodology/approach}

This study adopts a mixed methods approach and presents findings based on a series of semistructured interviews with management and self-completion questionnaires aimed at employees.

\section{Findings}

The relationship between the supervisor and the employee remains a key enhancer regarding engagement and employees are increasingly demanding more contemporary methods of communication. Employers should take note of generational characteristics and adopt flexible policies attractive to all employees.

\section{Practical implications}

This paper contributes to the debate regarding generational differences in the workplace, but also identifies that the various generations evident in tourism organisations are desirous of similar working conditions and benefits. Organisations should consider the development of a range of packages that focus on linking employees with their purpose, their colleagues and their resources as a means of encouraging employee engagement.

\section{Originality/value}

This study contributes to the debate regarding employee engagement and compares and contrasts initiatives that various tourism and hospitality organisations are adopting as a means of encouraging employee engagement. The study also elicits the views of the organisations employees in order to understand the extent of the effectiveness of such initiatives and makes recommendations regarding the most effective initiatives from both a management and employee perspective. 


\section{Introduction}

The extent of employee engagement in the hospitality and tourism industry can have implications for organisational effectiveness. Whilst engagement has been found to be at the discretion of the employee (Macey and Schneider, 2008), Shaw and Fairhurst (2008) argue that hospitality and tourism organisations can introduce strategies that can encourage engagement amongst employees, thus positively affecting effort and attitude and consequently, impacting on organisational success. Consequently, developing an understanding of the differing attitudes and expectations of work that employees in the hospitality and tourism industry possess is of interest to both researchers and practitioners alike. Indeed it has been argued that a better understanding of the particular characteristics that certain groups, or generations possess will go some way toward helping managers adopt appropriate management styles and introduce human resource policy as a means of better addressing the employment needs and expectations of particular groups of employees (Barron et al., 2007). Ruch (2005) highlights the importance of recognising generational issues and argues that for the first time in history, the general working population now comprises four generations working side-by-side, these being: Generation Y, Generation X, Baby Boomers and Matures. As a consequence, a number of studies (see for example, Park and Gursoy, 2012) have begun to explore the multi-generational workforce in the hospitality and tourism industry. Smith (2008, p.25) succinctly summarises the issue currently facing employers:

"The good news is that all generations basically want and value the same things. The bad news is that priorities, expectations, and behaviours may differ noticeably. People may want the same things, but they want them delivered in different packages, depending on when and how they grew up" 
It has been found that the most recent generation of employees (Generation Y, Millenniums) brings a number of characteristics to the workplace that subsequently translates into needs and expectations that are particular to this generational cohort. Consequently, Lub et al. (2012) stress the importance of tourism and hospitality employers understanding emerging generations as a means of appreciating employees' needs and expectations of the contemporary tourism and hospitality workplace. Indeed, it might be suggested that the demanding nature of (for example) Generation $\mathrm{Y}$ employees regarding their career expectations and aspirations could be considered as being a catalyst for change which might result in more flexibility and choice becoming available to all hospitality and tourism employees (Maxwell et al., 2010). Located within the hospitality and tourism industry and undertaken during a period of economic recession which has been found to influence employment issues (Cheese, 2010; Robinson and Rousseau, 1994; Robinson et al., 1994), this study recognises that employee engagement is essential to maximising both employee job satisfaction and organisational commitment.

\section{Purpose of the study}

Focussing on the multi-generational workforce, the aim of this study is to present strategies that hospitality and tourism organisations might adopt as a means of encouraging employee engagement, thus enabling the more effective management of an increasingly multigenerational workforce. The specific objectives of this paper are to:

1. Evaluate current strategies being adopted that might encourage employee engagement by a selection of hospitality and tourism organisations;

2. Analyse the level of engagement amongst the workforce in a range of tourism organisations; 
3. Highlight generational nuances and consequently enable employers to develop a deeper understanding of the multi-generational workforce;

4. Develop recommendations for organisations wishing to more effectively engage the multi-generational workforce.

\section{Employee Engagement}

The United Kingdom based Chartered Institute of Personnel and Development [CIPD] (2006 p.3) defined employee engagement as "involving feeling positive about your job as well as being prepared to go the extra mile to make sure you do your job to the best of your ability”. Christensen-Hughes and Rog (2008 p.749) identified the key drivers of employee engagement and opine that the level of trust and integrity that exists between the employee and organisation; the nature of the job; the connection between the individual employee and the company's' performance; career growth opportunities; pride in and about the company; their co-workers; opportunities for development; and the personal relationship with their manager, all have an effect on the level of engagement experienced by employees.

The concept of employee involvement in their organisation as a means of providing satisfying work was conceived and reported in the latter part of the $20^{\text {th }}$ century (Bowen and Lawler, 1992; Hackman and Oldham, 1975, 1976 and 1980; Renn and Vandenberg, 1995). Indeed affective job satisfaction, which reflects the degree of pleasure or happiness an employee experiences in their job (Thomson and Phua, 2012), has been the focus of a range of studies. However it has been argued that employees often have little influence over their level of job satisfaction as it is often greatly influenced by a range of factors (such as organisational policy) that are normally beyond their control (Shultz and Shultz, 2010). Employee engagement, on the other hand, can be influenced by a number of initiatives that 
organisations might adopt. However it has been found that the employee is the final arbiter of whether they are an engaged employee or not (CIPD, 2006). Kahn (1990) is acknowledged to be the first academic researcher to propose and examine the concept of engagement at work (Kim et al., 2009; Solnet and Kralj, 2010). Solnet and Kralj (2010) ascertained that, during the intervening twenty years, investigation and development of the employee engagement concept has been embraced much more enthusiastically within the business world than it has by the academic community (Macey and Schneider, 2008). This disparity is evident in the paucity of published articles identifiable (as ascertained by Bakker and Schaufeli, 2008), compared to the wide range of practitioner-developed employee engagement toolkits that are now generally available. However these toolkits often developed by or for major professional services consultancies such as Towers Perrin and Deloitte, tend not to have been subjected to rigorous testing within any academic research studies (Solnet and Kralj, 2010).

Woodruffe (2006) and Athey (2008a) propose that the top priority for consideration when attempting to increase employee engagement should be to improve communication both from the top downwards and from the bottom upwards. Athey (2008a; 2008b) suggests that by developing employees’ understanding their relevant purpose, developing close links with the people with whom they work and providing the resources required for them to undertake their job, an organisation will not only encourage employee engagement but also maximise employees own potential. This, it is suggested, will have a significant impact towards helping the organisation achieve its own goals. Indeed, organisations strive to influence and increase engagement amongst all employees as an engaged employee is more likely to be satisfied with their job (Salanova et al., 2005), less likely to leave the organisation (Saks, 2006; Schaufeli and Bakker, 2003) and display high levels of job performance (Halbesleben and Wheeler, 2008). 
From a macro perspective, Fairhurst (2008) reported that poor levels of employee engagement cost the UK economy almost $£ 40$ billion per year and a number of studies have concluded that this issue is forecast to continue, with those recently entering the workplace being distinctly less engaged at work compared to their older co-workers (Chao and Gardner, 2007; Solnet and Kralj, 2010; Worman, 2006). The seminal study conducted by the CIPD published in 2006 concluded that female employees, those employees on flexible contracts, managerial and supervisory employees, and crucially, older employees tended to be most engaged in their work. The CIPD survey found that, from an age perspective, only $25 \%$ of employees under 35 years of age were engaged in their work compared to around $40 \%$ of those aged over 35 (CIPD, 2006).

Whilst the positive aspects of emerging employee groups, (such as enthusiasm for change, possessing of ebullient personality and ready adoption of new technology) have been identified (see for example Kasavana et al., 2010; Leask, et al., 2011), researchers have increasingly concluded that work now appears to be less of a central feature in young people's lives as more emphasis is placed on creating a better work-life balance (CIPD, 2006; Harkinson, et al., 2011; Oliver, 2006). Table 1. below draws on the work of Ruch (2005), Consultrix (no date), Chen and Choi (2008) and Shaw and Fairhurst (2008) to outline the change in emphasis placed on work of each of the three major different generations evident in today’s workplace.

Table 1 - Here 
The above characteristics have stimulated a number of studies that have examined the employment needs and requirements specific to particular generations. Such studies draw similar conclusions: that employers are increasingly required to recognise the specific needs and expectations of all cohorts of workers in order to capitalise on their skills and experience (Feinsod et al., 2005; Honore and Paine Schofield, 2009; Smith, 2008). This recognition is becoming more important due to a combination of the ever shrinking pool of new recruits available to enter the workforce from the current emerging generation, and the recent abolition of the mandatory retirement age in the UK which is forecast to result in more people working for longer (Maitland, 2010).

The generational characteristics of employees (as identified above) have resulted in the identification of specific requirements and expectations' regarding an employees’ working experience (Glass, 2007). It has been found, for example, that older workers appreciate gaining appropriate recognition and respect for their contribution within the workplace whilst younger employees expect flexible working options (Armstrong-Stassen, 2008). It is therefore argued that employers are increasingly required to appreciate and respond to these expectations and requirements in order to maximise each employee's potential contribution towards meeting organisational objectives (Christensen-Hughes and Rog, 2008; Coupland et al., 2008; Sturges, 2008). For example, the CIPD (2006) suggested that organisations might introduce methods of creating opportunities for employee views and opinions to be heard (Christensen-Hughes and Rog, 2008; Gibbons, 2006); developing variable packages of benefits and working conditions (Smith, 2008; Worman, 2006); offering flexible working arrangements (Deery 2008; Rowley and Purcell, 2001); considering the meaningfulness of the work (Kahn, 1990; May et al., 2004); providing high quality supervisory support 
(Karatepe and Olugbade 2009; Kim et al., 2009); and, paying particular attention to personorganisation fit (Kristof, 1996; Schlosser and Zinni, 2011).

It has been suggested that the characteristics of the increasingly well-established presence of Generation Y within the general workforce is gradually influencing organisations to redefine the way that they engage with and manage their employees (Honore et al., 2009; Oliver, 2006). Recent studies have suggested that previous generational workforce cohorts have long desired to be afforded much the same considerations and allowances that the Generation $\mathrm{Y}$ cohort is now demanding (Bakker and Schaufeli, 2008; Worman, 2006). Consequently it might be argued that the ensuing changes to workforce management practices that have gradually been coming about as a result of Generation Y's entry into the workforce have also ultimately been to the benefit of employees from preceding generational cohorts (Maitland, 2010; Smith, 2008).

\section{The Industry Context}

The tourism and hospitality industry is reliant on being able to secure the right talent to fill the many and varied career and employment opportunities common in the industry (Barron, 2008). However, previous studies have suggested that the emergence of Generation Y into the workforce has created a significant level of turmoil within the industry due to the difficulty in retaining and engaging talented workers from this section of the workforce for whom undertaking meaningful, interesting and engaging work is of paramount importance (Barron, et al., 2007; McEwan, 2009). When discussing the level of commitment of emerging generations of employees in the hospitality industry, Lub et al. (2012) found that these cohorts have significantly lower levels of organisational commitment than employees from other generational groups and were consequently more likely to leave. It might therefore be 
concluded that this is especially concerning for industries, such as hospitality, that traditionally experience high levels of employee turnover (Davidson, et al., 2010) and rely on a steady supply of young people at a time where fewer young people are entering the workforce.

There is a plethora of research that suggests careers in tourism and hospitality are typified by low pay, seasonality, repetitive and monotonous tasks, unpleasant physical working conditions, anti-social working hours (see for example: Richardson, 2010; Solnet and Kralj, 2010). Indeed, the fact that these jobs are often regarded as low status occupations serves to increase human resource difficulties as these conditions do not fit at all with the values and attitudes of employees of any generation (Gursoy, et al., 2008; Solnet and Hood, 2008). For example when researching Generation $\mathrm{Y}$, students undertaking a tourism-related higher education qualification, Richardson (2010) found that at least one-third of these respondents indicated they did not want to pursue a career in the industry as a direct consequence of their experiences on their period of internship.

\section{Employee Engagement in the Tourism and Hospitality Industry}

Employee engagement is now actively being recognised as an integral element in any hospitality organisation's talent management strategy. Indeed it has been found that employers are increasingly using the recruitment and selection process as a means of identifying characteristics and traits that prospective employees possess that are indicators of a future committed and engaged worker (Raybould and Wilkins, 2005; Schlosser and Zinni, 2011; Scott and Revis, 2008). A review of the current talent management literature by Christensen-Hughes and Rog (2008) found that increasing numbers of tourism organisations now appear to be taking action to increase employee engagement with a view to minimising 
employee turnover and increasing both employee satisfaction and organisational commitment. This move is forecast to continue with Davidson et al., (2011 p.509) stating that “Generational change will continue to have a major impact on hospitality as the labour force is comprised of a relatively youthful profile”. These (youthful) employees, it is argued, will influence and indeed demand changes in the workplace in, for example, employee/employer communications and working conditions. Such changes are already evident with Chen and Choi (2008) concluding that younger managers and supervisors in the hospitality industry value quick promotion over intellectual stimulation and place more importance on a healthy work/life balance.

A number of researchers have identified that the talent management and engagement strategy most likely to be adopted by many employers is the traditional "attracting and retaining" approach (see for example, Athey, 2008a; Davidson et al., 2011). However, it is argued that this approach does not then seek to identify and incorporate the elements and aspects (such as their own personal development and deployment, rewards, communications and work-life balance) that matter most to and, therefore, generate the most value for their employees (Conway and Monks, 2008). An alternative approach, as proposed by Athey (2008a and 2008b), Demerouti, et al., (2001), Schaufeli and Bakker, (2003), and Kim et al., (2009) suggests that by linking an organisation's employees to their relevant purpose, the people with whom they have contact and the resources available, such employees will not only become both more engaged and more able to maximise their own potential, but also make a significant personal contribution towards helping the organisation achieve its goals.

As a means of promoting discourse and developing an understanding of the impact that generational issues have on the contemporary tourism workplace, and through the recognition 
of the identified characteristics of the emerging generations, the purpose of this study is to present strategies that hospitality and tourism organisations might adopt as a means of encouraging employee engagement, thus enabling a more effective management of an increasingly multi-generational workforce. It is considered that studies such as this will highlight generational nuances and consequently enable employers to develop a deeper understanding of this particular group of employees, thus enabling a more effective management of an increasingly multi-generational workforce.

\section{Research Methods Employed}

It is recognised that tourism and hospitality industry comprises a range of sectors and organisations and that employment within these sectors and organisations can vary. For example, employment conditions, such as low pay, seasonality, repetitive tasks and antisocial working hours (Solnet and Kralj, 2010) in hospitality organisations can differ from those common in other tourism organisations (Solnet and Hood, 2008). Indeed, such is the disparate nature of the wider tourism industry that it is common for there to be differences in pay and conditions across the various sectors of the industry. However, this study recognises that there are certain commonalities in employment patterns and practices across the industry (see for example Littlejohn and Watson, 2004) and therefore organisations from both the hospitality and tourism sectors were included in this study. A total of five organisations from the wider tourism sector were chosen to take part in this study. These five case organisations composed one medium size, four star hotel; a large visitor attraction; a tour company; and two outdoor adventure centres.

Data collection from each case study organisation was undertaken in two stages. Firstly, data were gathered via a semi-structured interview that was conducted with management 
personnel from each organisation. Based on Athey's (2008a) Connect to Engage study, informed by studies that have attempted to measure employee engagement (including: Conway and Monks, 2008; Demerouti, et al., 2001; Kim et al., 2009; Schaufeli and Bakker, 2003), and, as a consequence of a thorough review of the literature, a series of interview questions were developed. These were selected to enable the researchers to identify how management can encourage employee engagement and subsequently more fully understand employees’ enthusiasm and expertise and instil them with a greater sense of purpose.

These questions were focussed in three thematic areas. The first of these areas comprised questions that were based on identifying how the organisation connected their employees with their purpose or job. Areas covered in this section included questions focussed on practical issues such as recruitment, selection and orientation; and strategic issues such as how employees were involved in the organisation and the importance of ensuring potential employees feel passionate about work in general. The second thematic area concerned the relationships that exist in the workplace. Questions in this area included opportunities for both formal and informal discussion with supervisors and management; how the organisation encourages employees to develop appropriate professional relationships with customers; and mechanisms in place to ensure positive peer relationships. The third general area examined how the organisation provides the resources that employees need to effectively perform their role. Questions raised in this area included the availability of physical resources, training and development opportunities and the circulation of organisational information that may have an impact on job performance (e.g. financial performance). Running throughout the three thematic areas identified above was a focus on the impact of new technology and the emerging importance of social media as a means of communication. 
Management interviews were conducted with a senior member of the management team at each of the five organisations by two researchers. Of approximately one hour duration, data gathered from these interviews were recorded in note form, written up and both sets of notes combined during a post-interview discussion (between the researchers) in order to ensure that all responses were appropriately recorded. Data were typed and the content of each of the interviews were analysed. Based on the three thematic areas identified above, data were subject to manifest and latent coding and commonalities, differences and themes were therefore able to be identified. Each of these categories will be discussed in the results section below.

Secondly, data were gathered from employees via the completion of an online survey. Based on Athey's (2008b) study, this survey comprised a questionnaire that aimed to measure level of employee engagement. Specifically, the survey questionnaire comprised a total of 76 questions divided amongst 4 sections. The first section focussed on employees feelings regarding their connection to the purpose of their job; the second section concentrated on their relationships at work; the third section examined the resources required to effectively undertake their job; the fourth section asked for demographic data. The survey was conducted via a laptop that was placed in the staff room, thus encouraging staff to complete the questionnaire during breaks. Data were analysed using Survey Gizmo, an online survey toolkit which allowed for the collection and analysis of survey data.

Initially, a pilot study was conducted using management and employees at the visitor attraction. This scoping study comprised one management interview and 10 completed staff questionnaires. The interview questions and the survey questions were slightly adjusted in 
light of this initial scoping study. The findings from this scoping study were not used in the main study.

The total combined number of employees in the five case study organisations was 199: the breakdown being: 56 employees at the visitor attraction, 60 at the hotel, 55 at the tour company, and a combined total of 28 staff (14 staff at each site) at the two outdoor adventure centres. All employees in the participating organisations were invited to take part in the survey, thus all employees were asked questions relating to their own engagement with their organisation. In total, some 77 employees completed the survey questionnaire which equates to a total response rate of $38.7 \%$. $55.8 \%$ of all respondents were female and $44.2 \%$ were male. 53\% of all respondents represented Generation Y (i.e. between 16-30 years of age); 35\% were Generation X (i.e. between 31 and 46 years) and the remaining 12\% were Baby Boomers (i.e. over 47 years). $23.3 \%$ of all respondents held senior (i.e. managerial or supervisory) positions and the remaining $76.7 \%$ held non-supervisory positions. The low number of survey respondents in each individual organisation combined with the relatively even split between the two age ranges, that is 16-30 years of age and over-30 years of age, meant that in general it was not possible to draw many meaningful conclusions from the basic ANOVA statistical analysis carried out. A decision was therefore taken to combine the response data collected from all employees in each of the five of the case study organisations prior to any data analysis being carried out. The resulting combined results are presented in the following findings section.

The findings from the various research interviews and surveys conducted were compared and contrasted to develop a picture of employee engagement from both management and staff perspectives. The results highlight examples of best practice and identify particular 
opportunities that each case study organisation could consider implementing to further enhance employee engagement and performance.

\section{Results}

The following sections give examples, as drawn from the interview and survey data collected. Initially the most notable findings that either help (or hinder) employers in encouraging employee engagement are presented thematically under: Purpose of Employment; Relationships; and, Resources Required to be an Effective Employee. These are complemented by a summary of employees' perceptions drawn from the survey data collected about the different job dimensions that facilitate employee engagement.

As a means of introducing the findings from this study, Chart 1 below provides an overview of employees' positive responses to questions in these three areas. Questions relating to the three thematic areas (i.e. Purpose of Employment, Relationships, and Resources) were combined as a means of giving an overview of level of feeling amongst employees at the five organisations. It can be seen that employees from all organisations appeared positive regarding their responses to these areas. Employees generally felt a strong connection to their purpose and felt their relationships at work to be positive and supportive. Respondents also suggested that they possessed the resources necessary to undertake their job. Results from individual organisations and subsequent issues shall be further explored in the following section.

Chart 1 - Here 


\section{Purpose of Employment - Management Responses}

The managers at the visitor attraction, the hotel and the tour company advised that staff are encouraged to work in different areas and to shadow other employees to help them understand how their own work contributes to the bigger picture. In general, these findings conform to those of older studies undertaken by Hackman and Oldham (1975; 1976; 1980), Renn and Vandenberg (1995) and Bowen and Lawler, (1992). As evident in these studies, this study found that there is some attempt to understand the need for providing enriching employment experiences as a means of encouraging employee involvement and a demonstration of how their contribution assists in the achievement of organisational goals. An example of this is drawn from the visitor attraction that not only explains the role of employees during the induction period, but also undertakes an annual 'Projects Update' that explains the current situation of the organisation and invites all employees to address issues and develop new ideas, thus involving employees in often strategic level decisions. This appeared to occur throughout the year, with the visitor attraction manager stating that:

'There is a formal "Projects Update" meeting that highlights plans and projects for the forthcoming 12 months. This is supported by regular, interactive meetings where staff are encouraged to feedback on progress. This also gives staff the opportunity to accept elements of responsibility for specific projects’.

Managers from the outdoor adventure centres and the visitor attraction believe that placing more emphasis on personality than on technical ability during recruitment helps to gauge the likely degree of person-organisation fit. In contrast, the hotel and the tour company focused more on ascertaining what relevant practical skills and experience candidates held in particular job roles. For example, it was found that, as part of the selection process, the tour company and the visitor attraction require that applicants for new positions demonstrate their 
personality through the presentation of a 2-3 minute talk on a subject of their choice. This, it was considered, allowed prospective employees the opportunity to demonstrate both passion and personality through a topic that is of particular interest to the individual. Prospective employees of the outdoor adventure centres must also demonstrate an outgoing nature during the selection process where the organisation adopts a behavioural interview style during which applicants are presented with a range of hypothetical scenarios and required to suggest customer and organisational focussed solutions. The outdoor adventure centre manager stated that:

'This approach allows us to more effectively understand how an employee would deal with a particular scenario. It gives us some element of objective measure regarding potential behaviour'.

From these findings, and drawing on the work of previous researchers such as Kristof (1996), May (2003) and Schlosser and Zinni (2011), the researchers were surprised to note that the results from this study would indicate that organisations appear to place emphasis on either personality or technical skills during the recruitment and selection phase. It might be suggested that the organisations who took part in this study may be disadvantaged by only focussing their attention on only one aspect of a potential employees overall profile.

Similar to the findings of Christensen Hughes and Rog (2008) this study found that the visitor attraction manager reported that a number of former employees seek annual re-employment at the attraction because of the positive working conditions and friendly atmosphere. In contrast, the hotel appeared to be taking advantage of the current situation within the labour market whereby there is an oversupply of potential employees. At the hotel, there appeared to be a lack of focus on formal selection methods with 'gut feeling' on the part of the 
interviewer being as important as prior experience regarding employee selection. It was considered that the current employment situation may have the effect that being too career focussed could mean the loss of job security (and regular income) which employees could not risk. These findings would appear to be very similar to those obtained by earlier researchers such Robinson and Rousseau (1994) and Robinson et al., (1994) who found that such tendencies are often tempered during periods of economic downturn.

\section{Purpose of Employment - Employee Responses}

This study found that an average of $80 \%$ of respondents across all case study organisations stated that they were fully aware of the purpose of their employment. Chart 2, below, provides an overview of employee responses at the various organisations and it can be seen that employees at the Tour Company were almost universally aware of their employment purpose and their fit in the organisation. Given the fundamental issue of employment purpose, the organisation with the lowest (Outdoor Centre 1, with a respondent agreement rate of $73 \%$ ) may require to consider how employees can more effectively understand their role in the organisation.

\section{Chart 2 - Here}

Employees from the organisations were further asked to consider their overall attitude to their current position. Findings from this study suggest that whilst employees generally understood their role in the organisation, concurrent with this view 58\% of respondents considered work not to be a central defining feature in their lives. This finding accords well with previous studies such as Harkison et al. (2011); Chao and Gardner (2007); and Oliver (2006). In addition, and in agreement with the findings of Lub et al. (2012), this study also found a lack of loyalty to their current organisation (c/f. Davidson, et al., 2010), with an average of $40 \%$ 
of all respondents indicating their expectation, and indeed intention, to explore a range of other career opportunities with other employers at some point in the future with the aim of developing careers. Therefore, it might be argued that, whilst respondents were aware of their organisational fit, this study identified a moderately low level of work centrality which was combined with moderately high levels of careerism amongst this group of respondents.

The concept of careerism is linked to the percentage of employees who intended to leave the various organisations. There were organisational differences, with $47 \%$ of outdoor activity centre employees and $40 \%$ of hotel employees viewing their current employment as temporary. Whilst the seasonal nature of employment in the outdoor centre may contribute to this finding, it might be argued that the high level of potential leavers in the hotel continues the transient image of employment in hospitality as found by Richardson (2010) and Solnet and Kralj (2010) amongst others.

\section{Relationships - Management Responses}

The visitor attraction operated a buddy system that aims to link new members of staff with more experienced members, and by using this approach the manager stated that “... (they) feel that (they) easily and quickly become alerted to any issues arising in working relationships between employees... “. In contrast, the hotel puts the onus on individual employees to be proactive and work out who they can seek guidance or help from. The approach adopted by the hotel would appear to run contrary to the generally accepted wisdom as espoused by researchers such as Christensen-Hughes and Rog (2008), Gibbons (2006) and Athey (2008b) regarding the need to help facilitate connections between its employees in an effort to enhance levels of engagement. 
At both the visitor attraction and the outdoor adventure centres it was found that positive strategies to enhance relations between staff and management had been introduced. For example, the manager of the visitor attraction stated that “... staff have daily meetings with supervisors, and a communications team has also been established ... “. Whilst the manager at the at the outdoor adventure centre stated that “... staff are encouraged to say what they think and to be involved in some decision-making...”. In contrast, at the hotel, formal communication with staff is generally conducted indirectly using noticeboards and folders of information. Employees of the tour company's workforce also have limited opportunity to engage with supervisors as their work takes them off-site for most of the time. However, it might be suggested that all organisations understood the importance of good supervisor/employee relations as a means of developing an engaged workforce (Christensen Hughes and Rog, 2008).

Results from this study do, however, indicate the differences in approach adopted by various organisations and it might be suggested that relying on one-way communication probably does little to encourage and enable employees to voice their opinions and contribute to debate and decision-making. The management approach to supervisor relations with employees adopted by the hotel in particular would appear to run contrary to the best practice approach to employee management and engagement advocated by other researchers such as Kim et al. (2009) and Karatepe and Olugbade (2009).

The visitor attraction and the outdoor adventure centres all appear to encourage their employees to have their say rather than just appearing to go along with the general consensus. As a means of facilitating this, the visitor attraction organises visits to both competitor organisations and organisations with which the attraction has a professional association. 
Indeed the visitor attraction appears to value the development of relationships amongst its' employees with the manager stating that:

We organise a pre-season teambuilding party that is designed to encourage different groups of employees to work together. Relationships are also developed at post-season and Christmas parties and we actively encourage staff to socialise together through organising a number of out-of-work get-togethers.

Whilst this is encouraging and supports the views of other researchers such as ChristensenHughes and Rog (2008) and Gibbons (2006), this study found that the visitor attraction was unique in this approach and the more management driven approaches to communication and the sharing of information common in both the hotel and the tour company might perhaps indicate a preference for employees to conform to co-worker consensus.

\section{Relationships - Employee Responses}

The employees who took part in this study generally reported that they experienced good relations with their co-workers with an average across all organisations of $73 \%$ of respondents agreeing that their interactions with fellow employees were positive. This was especially true of respondents from the tour company where it was found that $91 \%$ of respondents considered they enjoyed positive relationships with fellow employees - a significant finding considering the disparate nature of employment in this organisation. A majority (77\%) of hotel employees also enjoyed positive relationships as did the outdoor adventure centres (70\% and 64\%) and the visitor attraction (65\%). These results are summarised in Chart 3 below. Respondents were also asked to comment on the level of support they received from their supervisor with a majority (73\%) of respondents from all 
organisations reported that relationships with immediate supervisors were generally supportive. All of which aligns neatly with the assertions of Athey (2008a and 2008b).

\section{Chart 3 - Here}

\section{Resources Required to be an Effective Employee - Management Responses}

At the visitor attraction, staff were actively involved in the development of a formal, multimodule system of work-related education that was available to be undertaken by all employees. The organisation did, however, seem to be reticent about introducing IT-based communications mechanisms with the manager suggesting it “... offers no particular advantages to them and have concerns that they may even be a drain on management resources...”. The attitude of caution regarding venturing too far toward new means of communication appeared universal amongst all organisations that took part in this study, with the hotel and the outdoor adventure centres holding similar views. At the hotel, a traffic light system is employed to help identity training need based on level of competence in particular subjects or skills. However, as not all staff participate in the appraisal process it is likely that the needs of some employees may easily be overlooked. Whilst the tour company has created an online forum that is used to encourage communication between the mobile workforce, given the isolated nature of positions, it was surprising to find that that the organisation does not provide its employees with mobile technology as a standard part of their job toolkit. The apparent reluctance of management to employ now-commonplace physical resources such as social media and even online training packages as a means of engaging employees in their work appears to be at odds with accepted engagement best practice as established by previous researchers such as Kasavana et al. (2010). 
The managers of the visitor attraction recognised the need to help their employees maintain a good work-life balance. Similarly, the hotel attempts to ensure that employees have 2 days’ rest each week; however this was not always possible depending on the needs of the business. Recharging emotionally and psychologically is difficult for the tour company's mobile workforce as they are constantly on the move and they do not socialise with their tour groups. Encouragingly, though, tour company employees surveyed did generally report that overall they felt they were able to maintain a good work-life balance - essential for encouraging engagement (Harkinson et al., 2011). Managers of the outdoor adventure centres were happy for their employees to take time out or make use of other facilities nearby in order to recharge their energies. In line with the recommendations about flexible working made by both Rowley and Purcell (2001) and Deery (2008), working hours for employees of the visitor attraction, the hotel and the outdoor adventure centres are negotiated and agreed well in advance. However, the manager of the outdoor adventure centre did acknowledge that “... operating with this degree of flexibility can introduce difficulties, particularly at weekends which is when the organisation does about $60-70 \%$ of all its business...”.

\section{Resources Required to be an Effective Employee - Employee Responses}

Chart 4, below, provides an overview of employee responses regarding access to necessary resources required to effectively undertake employment requirements. It can be seen that a majority of survey respondents felt that they had access to the necessary physical resources that allowed them to perform their job adequately. However, results detailed below do indicate that a significant minority (e.g. approximately $40 \%$ across all organisations) of employees indicate they lack the appropriate resources that allow them to undertake their job

effectively. When asked what resources were lacking, those employees displaying concern 
indicated that access to particular resources such as training, technology, tools and systems, and to particular people were problematic. Further examination of data revealed that from this study would suggest such employee concerns might be as a consequence of managerial resistance when it came to employing technology as a means of enhancing relationships between employees and management/supervisory staff.

\section{Chart 4 - Here}

Generational differences were highlighted in this element of the study with Generation Yaged respondents from the hotel and tour company desiring the opportunity to utilise the same online resources for socialising and information exchange in both their personal and professional lives. This study also identified that $25 \%$ of respondents from all organisations were feeling emotionally challenged by their work, and that the nature and pressure of their jobs did not allow them the necessary cushion of time and space that they required to enable them to re-energise themselves adequately during the day.

\section{Conclusion}

This study aimed to present strategies that hospitality and tourism organisations might adopt as a means of encouraging employee engagement. By evaluating the level of engagement of employees in a selection of tourism and hospitality organisations, this study has also identified common approaches and highlighted areas of good practice. This, it is suggested, will enable the more effective management of an increasingly multi-generational workforce. The results of this study would broadly indicate that some organisations are recognising the benefits of developing an engaged workforce and are adopting a range of policies aimed at encouraging engagement amongst employees. 
The findings would also suggest that there is a growing recognition of the existence of emerging cohorts of employees (such as Generation Y) as an increasingly important element of the workforce who possess different characteristics and workplace needs. As found in previous research in the hospitality and tourism industry (see for example: Raybould and Wilkins, 2005; Scott and Revis, 2008), this would appear to commence during the recruitment and selection phase with evidence from this study suggesting that organisations are keen to quickly develop employee's understanding of the purpose of their job, develop relationships with the people with whom they will come into contact and understand the various resources available for them to undertake their work effectively.

Whilst tourism and hospitality industry specific skills and experience continue to be important, an important finding of this study suggests that organisations appear to be increasingly valuing the personal attributes of prospective employees over industry specific skills and knowledge. Organisations that took part in this study appear to place more emphasis on selection practices that allow for the assessment of a candidates' personality and consider that the development of organisation-specific and technical skills can occur once employed. Whilst employees’ personality traits are of significant importance, especially in service orientated positions, it is argued that organisations that place too much emphasis on personality over technical skills are placing themselves at a disadvantage. Consequently, it is suggested that adopting a more balanced approach to selection would allow access to the large pool of currently untapped, industry specific talent that is being overlooked by organisations in their drive to recruit on personal attributes alone. 
It was interesting to note that the organisations who took part in this study generally recognised the employment process as being a long-term activity involving the provision of high-quality personal support, for example through the use of a formal buddy system, that was tailored to the specific needs of the individual. This approach ensured that such employees became productive members of staff in the shortest possible time. It might however, be suggested that evidence from this study indicates that finding ways to address the rather demanding, but increasingly common, needs and expectations of emerging generations of employees has resulted in some of these specific practices becoming the norm. Whilst this study found that organisations attempt to encourage engagement amongst employees, the results of the employee survey do however perpetuate the idea of careers in the tourism and hospitality industry being temporary. The combination of employment not being a central feature in ones' life; a lack of organisational loyalty; and an intention to leave would indicate that generational characteristics are going some way to perpetuating commonly held industry employment traits. This was especially the case amongst hotel and outdoor activity organisation employees.

In line with many studies that focus on employee engagement, this research found that communication had a significant influence regarding the level of engagement that an employee feels with their employer. The tourism organisations that took part in this study utilised a range of methods; ranging from fairly traditional approaches, such as formal meetings, memos and notice boards which have proven to work well for all generations, to the use of contemporary communication methods such as texting which are viewed as normal to members of Generation Y. The minimal use of various social media such as Facebook or Twitter as a formal means of communication was an unexpected finding, and given the increasing adoption of social media (especially amongst Generation Y) as a primary method 
of communication, coupled with employee desire for such methods of communication, it might be suggested that organisations explore the costs and benefits of introducing such an approach. All organisations valued employee development and viewed this not only as a means of providing skills and knowledge that allowed employees to work harder and more efficiently, but also in recognition of the individual's desire for self-improvement. However, the use of new technologies as a means of supporting skill and knowledge development was not as prevalent as had been expected.

The relationships that employees enjoy at work can have a significant impact on their engagement and this study found that, in general, respondents experienced positive relationships. However, it was noted that employees at the Tour Company reported very high levels of relationships at work. Given the nature of this organisation - where employees are often working alone and off-site - this is an unusual finding and suggests that this organisation has success in encouraging relationships amongst its workers in what could be considered adverse conditions. Thus, it is concluded that further examination of how this organisation achieves this outcome is conducted with the aim of more fully understanding how this example of good practice occurs.

Generally, it is concluded that this study appears to concur with previous studies (Barron, et al., 2007; CIPD, 2006; Glass, 2007; Leask, et al., 2013; Lub et al., 2012; Smith, 2008) that have identified the importance of understanding different generational needs. However it was interesting to note that several organisations who took part in this study did not place importance on, or indeed recognise the existence of, differences in employee characteristics of different generations. However, it might be concluded that the shrinking youth labour market and the potential increase in the availability of older workers may result in the 
creation of a workplace that increasingly contains employees from both ends of the generational spectrum and consequently increase the importance of understanding different generational needs and wants.

This situation may be exacerbated in industries such as tourism and hospitality who have traditionally relied on a steady supply of young workers, but who may, in the future, look to other generational cohorts to fulfil their employment requirements. Consequently, it is suggested that whilst many human resource policies are focussed on the latest generation of workers, tourism organisations should be wary of ignoring employees from other generational cohorts. Indeed, organisations might consider the development of a range of policies that encourage employees to construct individual packages which take into account individual generational nuances, needs and expectations. Such packages will encourage engagement through allowing employees to connect with their purpose, their people and their resources in a manner that recognises generational characteristics, values traditional and contemporary Human Resource Management approaches and ultimately enhances employee engagement in the tourism industry.

Like all research, this study has a number of limitations which the authors attribute to the relative weakness of interviews to present valid, reliable and trustworthy empirical evidence; and also the relatively small number of completed employee surveys. Consequently, it is recognised that the results of this study present a snapshot of feelings amongst a specific group of management and employees at the participant organisations, at a particular point in time. Although the authors make no claims regarding generalisability of the results, undertaking this study has further contributed to the debate regarding the impact of generational characteristics on employee engagement. In addition to progressing academic 
discussion, the findings of this study are potentially of interest to tourism and hospitality organisations whose strategy is to attract, retain, manage and especially motivate employees through developing connections with purpose, people and resources.

\section{References}

Armstrong-Stassen, M. (2008), “Organisational practices and the post-retirement employment experience of older workers”, Human Resource Management Journal, Vol. 18 No. 1, pp. 36-53.

Athey, R. (2008a), "It's 2008; Do you know where your talent is? Why acquisition and retention strategies don't work". Retrieved August 30, 2012, from http://www.deloitte.com/assets/DcomSlovakRepublic/Local\%20Assets/Documents/DTT_DR_Talent_final\%2005(1).pdf

Athey, R. (2008b), "It's 2008; Do you know where your talent is? Connecting people to what matters”. Retrieved August 30, 2012, from http://www.deloitte.com/assets/DcomUnitedKingdom/Local\%20Assets/Documents/UK_C_ConnectingPeopletoWhatMatte rs.pdf

Bakker, A.B. and Schaufeli, W.B. (2008), "Positive organisational behaviour: engaged employees in flourishing organisations", Journal of Organisational Behaviour, Vol. 29, pp. 147-154.

Barron, P. (2008), "Education and talent management: implications for the hospitality industry”, International Journal of Contemporary Hospitality Management, Vol. 20 No. 7, pp. 730-742.

Barron, P., Maxwell, G. A., Broadbridge, A. and Ogden, S. (2007), "Careers in hospitality management: generation Y's experiences and perceptions", Journal of Hospitality and Tourism Management, Vol. 14 No. 2, pp. 119-128.

Bowen, D. E. and Lawler, E. E., III. (1992), "The empowerment of service workers: what, why, how, and when”, Sloan Management Review, Vol. 33 No. 3, pp. 31-39.

Conway, E. and Monks, K. (2008), "HR practices and commitment to change: an employeelevel analysis”, Human Resource Management Journal, Vol. 18 No. 1, pp. 72-89.

Chao, G. T. and Gardner, P. D. (2007), "How central is work to young adults?" Retrieved 11 Nov, 2011, from http://ceri.msu.edu/publications/pdf/work_young_adults.pdf

Cheese, P. (2010), "Talent management for a new era: what we have learned from the recession and what we need to focus on next", Human Resource Management International Digest, Vol. 18 No. 3, pp. 3-5.

Chen. P.J. and Choi, Y. (2008), "Generational differences in work values: a study of hospitality management". International Journal of Contemporary Hospitality Management, Vol. 20 No. 6, pp. 595-615.

Christensen-Hughes, J. and Rog, E. (2008), “Talent management: a strategy for improving employee recruitment, retention and engagement within hospitality organizations”, International Journal of Contemporary Hospitality Management, Vol. 20 No. 7, pp. 743-757.

CIPD. (2006), “How engaged are British employees?” Report Summary. Retrieved 27 July, 2011, from http://www.cipd.co.uk/NR/rdonlyres/E6871F47-558A-466E-9A744DFB1E71304C/0/howengbritempssr.pdf 
Consultrix. (no date). "Who will fill your shoes when you retire?” Retrieved 24 July, 2012, from http://www.consultrix.co.uk/downloads/newsletters/Consultrix-GenerationY.pdf

Coupland, C., Tempest, S. and Barnatt, C. (2008), "What are the implications of the new UK age discrimination legislation for research and practice?" Human Resource Management Journal, Vol. 18 No. 4, pp. 423-431.

Davidson, M., McPhail, R. and Barry, S. (2011), "Hospitality HRM: past, present and the future”. International Journal of Contemporary Hospitality Management, Vol. 23 No. 4, pp. 498-516.

Davidson, M., Timo, N. and Wang, Y. (2010), "How much does labour turnover cost? A case study of Australian four- and five-star hotels". International Journal of Contemporary Hospitality Management, Vol. 22 No. 4, pp. 451-466.

Deery, M. (2008), “Talent management, work-life balance and retention strategies”, International Journal of Contemporary Hospitality Management, Vol. 20 No. 7, pp. 792-806.

Demerouti, E., Bakker, A. B., Nachreiner, F. and Schaufeli, W. B. (2001), "The job demandsresource model of burnout”. Journal of Applied Psychology, Vol. 86 No. 3, pp. 499512.

Fairhurst, D. (2008), “Am I 'bovvered'? Driving a performance culture through to the front line”. Human Resource Management Journal, Vol. 18 No. 4, pp. 321-326.

Feinsod, R., Davenport, T. and Arthurs, R. (2005), "The business case for workers aged 50+: planning for tomorrow's talent needs in today's competitive environment”. Report produced by Towers Perrin for AARP, Washington DC: December 2005. Accessed on 22 June 2012 at http://assets.aarp.org/rgcenter/econ/workers_fifty_plus.pdf .

Gibbons, J. (2006), "Employee engagement: A review of current research and its implications”. New York, NY: The Conference Board.

Glass, A. (2007), "Understanding generational differences for competitive success". Industrial and Commercial Training, Vol. 39 No. 2, pp. 98-103.

Gursoy, D., Maier, T. A. and Chi, C. G. (2008), "Generational differences: an examination of work values and generational gaps in the hospitality workforce". International Journal of Hospitality Management, Vol. 27 No. 3, pp. 448-458.

Hackman, J. R., and Oldham, G. R. (1975), “Development of the Job Diagnostic Survey”. Journal of Applied Psychology, Vol. 60 No. 2, pp. 159-170.

Hackman, J. R. and Oldham, G. R. (1976), "Motivation through the design of work: test of a theory”. Organizational Behavior and Human Performance, Vol. 16 No. 2, pp. 250279.

Hackman, J. R. and Oldham, G. R. (1980), “Work Redesign”. Reading, MA: AddisonWesley.

Halbesleben, J. and Wheeler, A. (2008), “The relative roles of engagement and embededness in predicting job performance and intention to leave”, Work \& Stress, Vol. 22 No. 3, pp. 242-256.

Harkinson, T., Poulston, J. and Kim, J.-H. G. (2011), "Hospitality graduates and managers: the big divide". [DOI: 10.1108/09596111111122541]. International Journal of Contemporary Hospitality Management, Vol. 23 No. 3, pp. 377-392.

Honore, S. and Paine Schofield, C. (2009), "Gen Y: Inside Out. A multi-generational view of Generation Y - learning and working”. Berkhamsted, Hertfordshire: Ashridge Business School.

Kahn, W. A. (1990), "Psychological conditions of personal engagement and disengagement at work”. Academy of Management Journal, 33(4), 692-724. 
Karatepe, O. M. and Olugbade, O. A. (2009), "The effects of job and personal resources on hotel employees' work engagement”, International Journal of Hospitality Management, Vol. 28 No. 4, pp. 504-512.

Kasavana, M. L., Nusair, K. and Teodosic, K. (2010), “Online social networking: redefining the human web”, Journal of Hospitality and Tourism Technology, Vol. 1 No. 1, pp. 68-82.

Kim, H. J., Shin, K. H. and Swanger, N. (2009), "Burnout and engagement: A comparative analysis using the Big Five personality dimensions”. International Journal of Hospitality Management, Vol. 28 No. 1, pp. 96-104.

Kristof, A. L. (1996), "Person-organisation fit: an integrative review of its conceptualisations, measurements and implications”. Personnel Psychology, Vol. 49 No. 1, pp. 1-49.

Leask, A. Fyall, A. and Barron, P. (2013), "Generation Y: opportunity or challenge strategies to engage Generation $\mathrm{Y}$ in the UK attractions' sector", Current Issues in Tourism, Vol. 16 No. 1, pp17-46.

Littlejohn, D. and Watson, S. (2004), "Developing graduate managers for hospitality and tourism”, International Journal of Contemporary Hospitality Management, Vol. 16 No. 7, pp 408-414.

Lub, X., Bijvank, M.N., Bal, M., Blomme, R. and Schalk, R. (2012), “Different or alike?: Exploring the psychological contract and commitment of different generations of hospitality workers". International Journal of Contemporary Hospitality Management, Vol. 24 No. 4, pp. 553-573.

Macey, W. and Schneider, B. (2008), “The meaning of employee engagement”. Industrial and Organisational Psychology, Vol. 1, pp. 3-30.

Maitland, A. (2010), “Working better: the over 50s, the new work generation”. Report produced for the Equality and Human Rights Commission, January 2010. Retrieved 1 July 2012 from http://www.equalityhumanrights.com/uploaded_files/publications/workingbetter_over -50s.pdf

Maxwell, G., Ogden, S. and Broadbridge, A. (2010), “Generation Y's career expectations and aspirations: engagement in the hospitality industry". Journal of Hospitality and Tourism Management, Vol. 14, pp 53-61.

May, D. R., Gilson, R. L. and Harter, L. M. (2004), "The psychological conditions of meaningfulness, safety and availability and the engagement of the human spirit at work”. Journal of Occupational and Organizational Psychology, Vol. 77 No. 1, pp. 11-37.

McEwan, A. M. (2009), “Generation Y: coming to a workplace near you”. Retrieved August 24, 2012, from http://www.thesmartworkcompany.com/pdf/GenY.pdf

Oliver, D. (2006), "An expectation of continued success: the work attitudes of Generation Y”, Labour and Industry, Vol. 17 No. 1, pp. 61-84.

Park, J. and Gursoy, D. (2012), "Generational effects on work engagement among US hotel employees”, International Journal of Hospitality Management Vol. 31 No. 4, pp 1195-1202.

Raybould, M. and Wilkins, H. (2005), "Over qualified and under experienced: turning graduates into hospitality managers”. International Journal of Contemporary Hospitality Management, Vol. 17 Nos. 2/3, pp. 203-216.

Renn, R. W. and Vandenberg, R. J. (1995), “The critical psychological states: an underrepresented component in job characteristics model research". Journal of Management, Vol 21 No. 2, pp. 279-303. 
Richardson, S. (2010), "Understanding Generation Y's attitudes towards a career in the industry”. In P. Benckendorff, G. Moscardo and D. Pendergast (Eds.), Tourism and Generation $Y$ (pp. 131-142). Cambridge, MA: CAB International.

Robinson, S. L. and Rousseau, D. M. (1994), "Violating the psychological contract: not the exception but the norm”. Journal of Organizational Behavior (1986-1998), Vol. 15 No. 3, pp. 245-259.

Robinson, S. L., Kraatz, M. S. and Rousseau, D. M. (1994), "Changing obligations and the psychological contract: a longitudinal study”. Academy of Management Journal, Vol. 37 No. 1, pp. 137-152.

Rowley, G. and Purcell, K. (2001), “'As cooks go, she went': Is labour churn inevitable?” International Journal of Hospitality Management, Vol. 20 No. 2, pp. 163-185.

Ruch, W. (2005). Full engagement. Leadership Excellence. Vol. 22 No. 12, p.11.

Saks, A.M. (2006), “Antecedents and consequences of employee engagement”, Journal of Managerial Psychology, Vol. 21 No. 7, pp. 600-619.

Salanova, M. Agut, S. and Peiro, J.M. (2005), "Linking organizational resources and work engagement to employee performance and customer loyalty: the mediation of service climate”. Journal of Applied Psychology, Vol. 90 No. 6, pp. 1217-1227.

Schaufeli, W. B. and Bakker, A. B. (2003), "UWES: Utrecht work engagement scale: Preliminary manual”. Version 1, November 2003. Retrieved 10 March, 2012, from http://www.schaufeli.com/downloads/tests/Test\%20manual\%20UWES.pdf

Schlosser, F.K. and Zinni, D.M. (2011), "Transitioning ageing workers from paid to unpaid work in non-profits”. Human Resource Management Journal, Vol. 21 No. 2, pp. 156170.

Scott, B. and Revis, S. (2008), “Talent management in hospitality: graduate career success and strategies”. International Journal of Contemporary Hospitality Management, Vol. 20 No. 7, pp. 781 - 791.

Schultz, D. P. and Schultz, S. E. (2010), "Psychology and work today: an introduction to industrial and organizational psychology" (10th ed.). Upper Saddle River, N.J.: Prentice Hall. ISBN 978-0205683581.

Shaw, S. and Fairhurst D. (2008), "Engaging a new generation of graduates". Education + Training, Vol. 50 No. 5, pp. 366-378.

Smith, W. S. (2008), "Decoding generational differences: fact, fiction... or should we just get back to work? Retrieved October 19, 2011, from http://public.deloitte.com/media/0507/250608/us_DecodingGenerationalDifferences.p $\mathrm{df}$

Solnet, D. and Hood, A. (2008), “Generation Y as hospitality employees: framing a research agenda”, Journal of Hospitality and Tourism Management, Vol. 15, pp. 59-68.

Solnet, D. and Kralj, A. (2010), "Can't get no satisfaction: an examination of generation $Y$ work attitudes”. Paper presented at the 2010 International CHRIE Conference 28 - 31 July $2010 . \quad$ Retrieved from http://scholarworks.umass.edu/refereed/CHRIE_2010/Friday/4/

Sturges, J. (2008), “All in a day's work? Career self-management and the management of the boundary between work and non-work", Human Resource Management Journal, Vol. 18 No. 2, pp. 118-134.

Thompson, E.R. and Phua F.T.T. (2012), “A brief Index of affective job satisfaction". Group \& Organization Management, Vol. 37 No. 3, pp. 275-307. doi:10.1177/1059601111434201

Woodruffe, C. (2006), “From 'Whatever' to 'My pleasure': how can employers increase engagement?” Reflections on employee engagement (pp. 8-10). London: CIPD. 
Worman, D. (2006), "When it comes to being engaged at work, are employees different or the same?” Reflections on employee engagement (pp. 11-12). London: CIPD.

Please note that the authors would be happy to supply copies of the staff survey questionnaire and/or the interview questions on request.

\begin{tabular}{|c|c|c|c|}
\hline & $\begin{array}{l}\text { Baby Boomers (typically } \\
\text { born between 1946-1964) }\end{array}$ & $\begin{array}{l}\text { Generation X (typically } \\
\text { born between 1964-1979) }\end{array}$ & $\begin{array}{l}\text { Generation Y (typically } \\
\text { born between 1979-1994) }\end{array}$ \\
\hline $\begin{array}{l}\text { Work ethic and } \\
\text { values }\end{array}$ & $\begin{array}{l}\text { Workaholics who work } \\
\text { efficiently for personal } \\
\text { fulfilment; } \\
\text { - } \quad \begin{array}{l}\text { Desiring of quality and } \\
\text { question authority }\end{array}\end{array}$ & $\begin{array}{l}\text { - } \\
\text { walf-reliant, but also } \\
\text { want structure \& } \\
\text { direction. }\end{array}$ & $\begin{array}{ll}\text { - } & \text { Can multi-task; } \\
\text { - } & \text { Tenacious and } \\
\text { entrepreneurial; } \\
\text { - } & \text { Tolerant and goal } \\
\text { oriented. }\end{array}$ \\
\hline Interactive style & • $\quad$ Team player. & - $\quad$ Entrepreneur. & - $\quad$ Participative. \\
\hline Communications & - $\quad$ In person & - $\quad$ Direct and Immediate & - $\quad$ Social media \\
\hline $\begin{array}{l}\text { Feedback \& } \\
\text { rewards }\end{array}$ & - Money and recognition & $\begin{array}{ll}- & \text { Require regular } \\
\text { feedback } \\
\text { - } & \text { Value autonomy }\end{array}$ & $\begin{array}{ll}- & \text { Require constant } \\
& \text { feedback } \\
\text { - } & \text { Reward through } \\
& \text { meaningful work }\end{array}$ \\
\hline $\begin{array}{l}\text { Work/life } \\
\text { balance }\end{array}$ & - $\quad$ Poor work life balance & $\begin{array}{l}\text { Value balance between } \\
\text { work and personal life }\end{array}$ & $\begin{array}{l}\text { - Life outside work } \\
\text { viewed as more } \\
\text { important }\end{array}$ \\
\hline $\begin{array}{l}\text { Example of } \\
\text { engagement }\end{array}$ & - $\quad$ Personal development & - $\quad$ Intellectual stimulation & $\begin{array}{ll} & \text { Social interaction } \\
\text { between employees }\end{array}$ \\
\hline
\end{tabular}

Table 1: Summary of Different Generational Workplace Characteristics (adapted from Ruch 2005; Consultrix, no date; Chen and Choi, 2008; Shaw and Fairhurst, 2008).

\begin{tabular}{|c|c|}
\hline Area & Employment Issue \\
\hline Attitude to work & $\begin{array}{l}\text { - Work is considered less central to life. } \\
\text { - } \text { Remanding a better and healthier work/life balance. } \\
\text { - Require flexibility at work - tasks, time and tenure. }\end{array}$ \\
\hline Communication & $\begin{array}{l}\text { - Opportunity to communicate views and opinions to senior } \\
\text { management. } \\
\text { - Views and opinions are valued and acted upon. } \\
\text { - Utilisation of new technology. }\end{array}$ \\
\hline Conditions & - Bespoke packages of working conditions and rewards. \\
\hline Advancement & $\begin{array}{l}\text { - } \quad \text { Regular and timely feedback. } \\
\text { - } \quad \text { Opportunity for quick promotion. }\end{array}$ \\
\hline Connections & $\begin{array}{l}\text { - Appropriate fit to the purpose of employment. } \\
\text { - } \quad \text { Avase link to fellow employees and consumers. } \\
\text { performance. }\end{array}$ \\
\hline
\end{tabular}


Table 2: Summary of key employee engagement issues relating to the Generation Y employee (From: Armstrong-Stassen, 2008; Athey, 2008a; Athey, 2008b; Barron, et al, 2007; CIPD, 2006; Chen and Choi, 2008; Christensen-Rog and Hughes, 2008; Deery, 2008; Demerouti, et al, 2001; Gibbons, 2006; Harkison, et al, 2011; Kasavana et al, 2010; Kim, et al, 2009; Leask, et al, 2011; McEwan, 2009; Oliver, 2006; Rowley and Purcell, 2001; Ruch, 2005; Shaw and Fairhurst, 2008; Sclosser and Zinni, 2011; Smith, 2008; Woodruffe. 2006; Worman, 2006). 


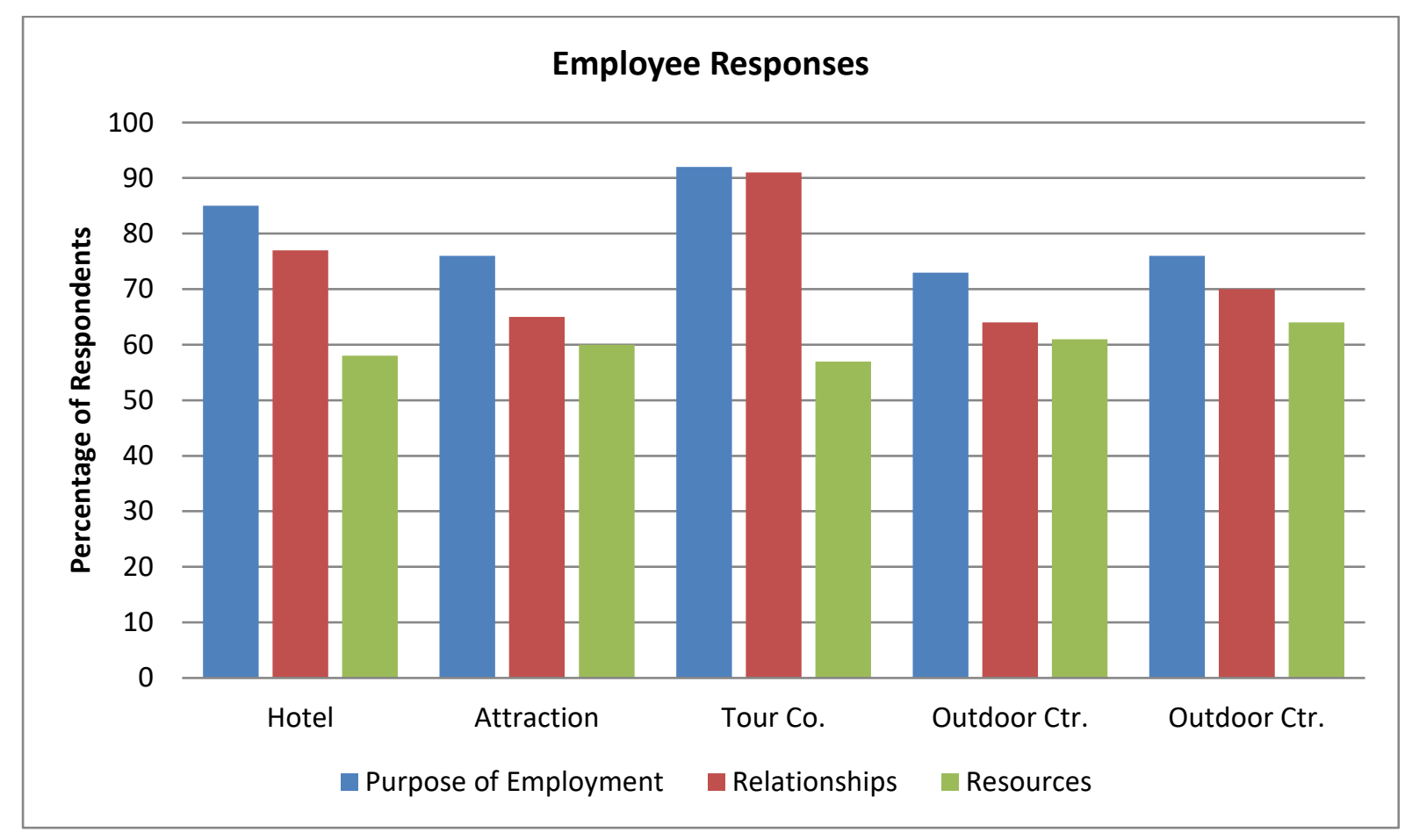

Chart 1: Summary of employee responses

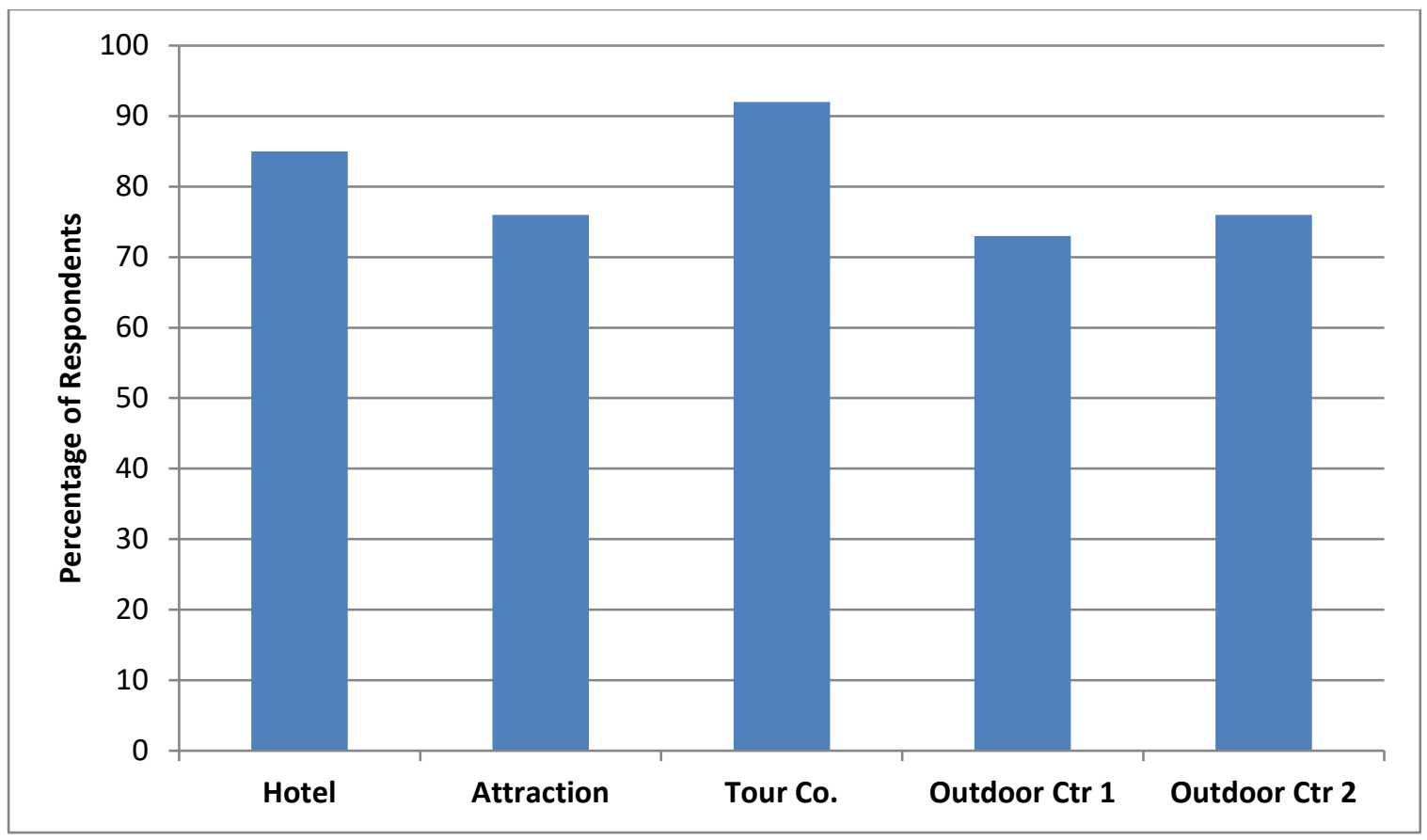

Chart 2: Purpose of Employment - Employee responses 


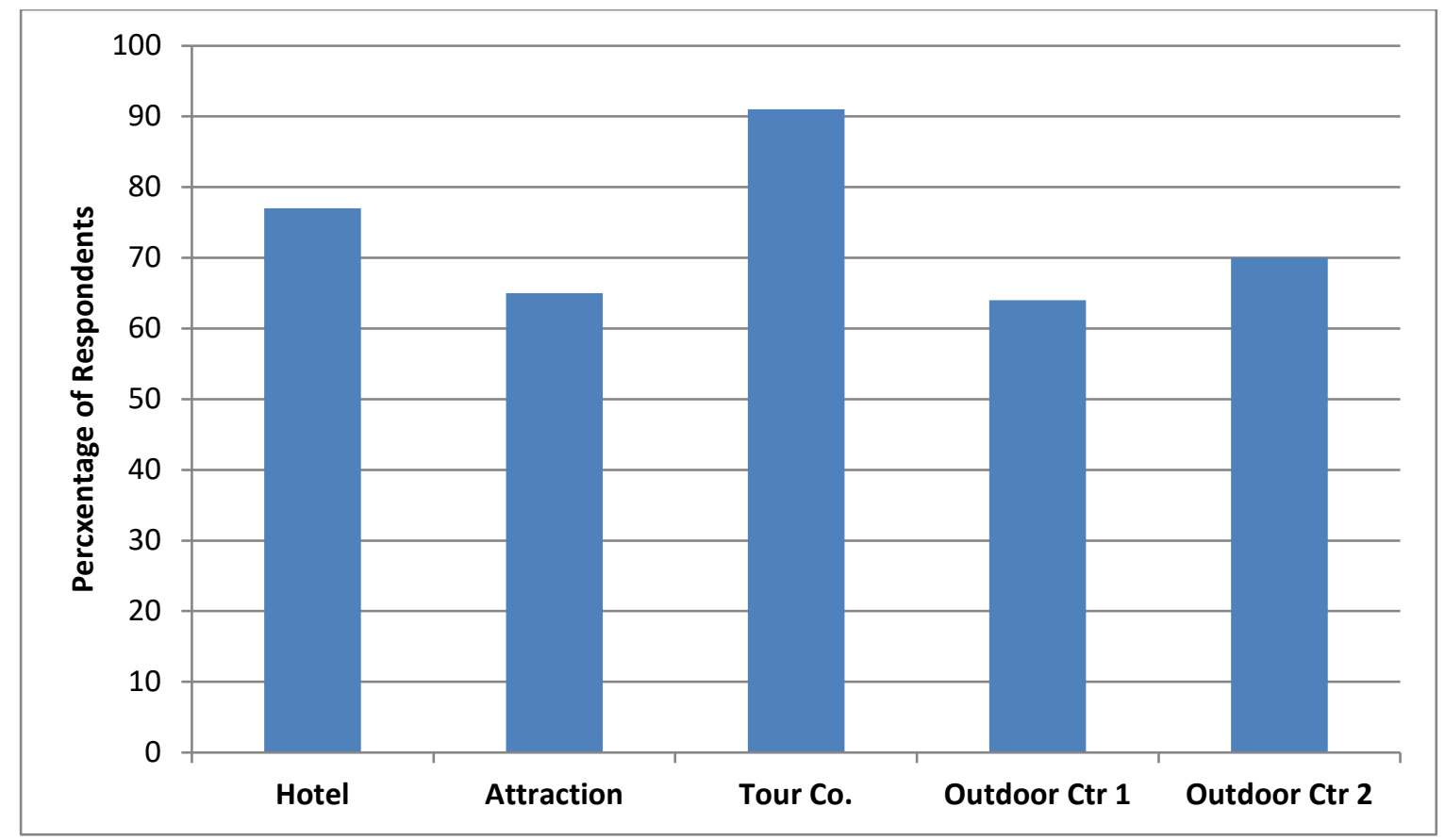

Chart 3: Relationships at work - Employee responses

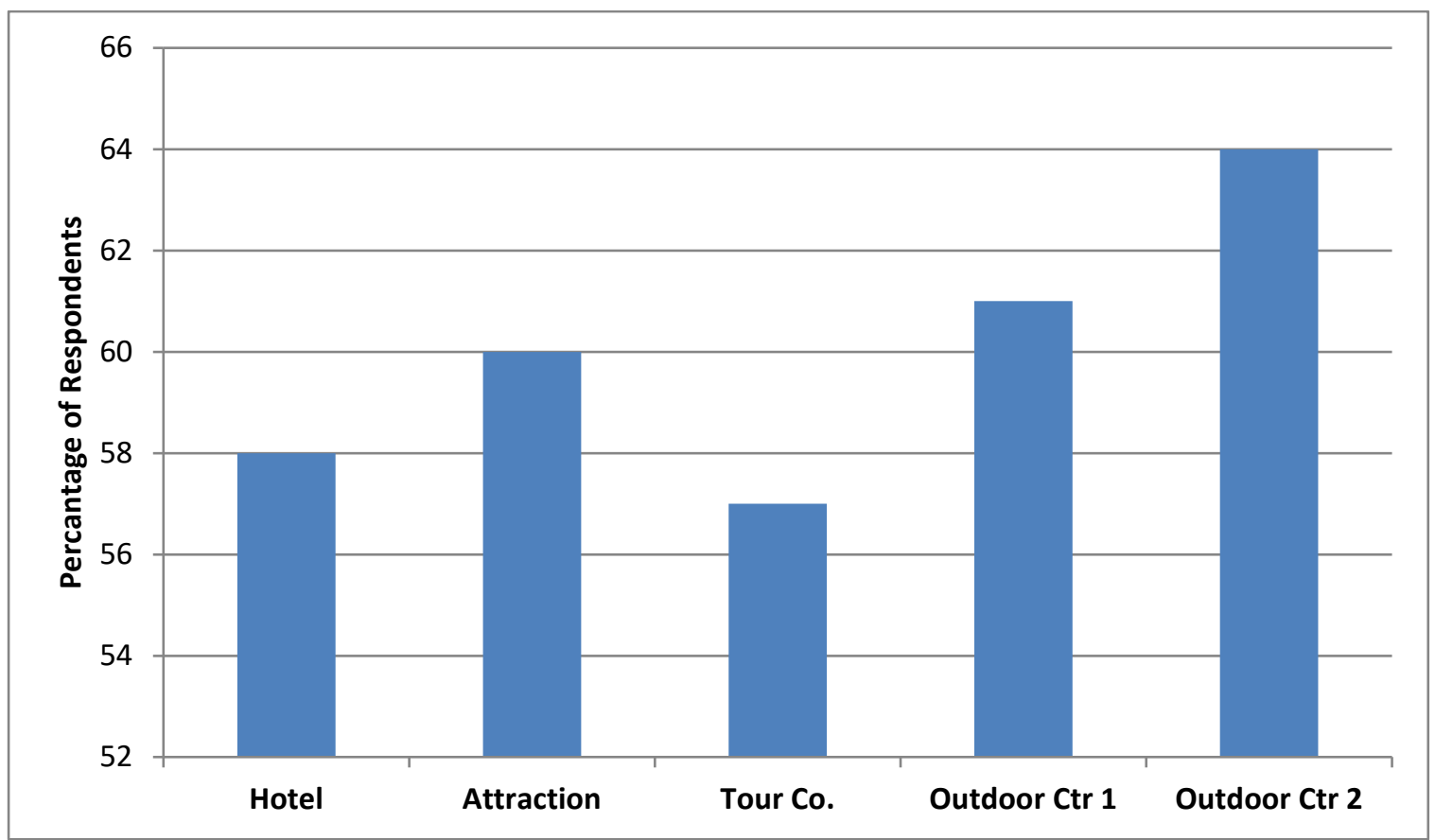

Chart 4: Resources required for effective employment - Employee responses 
